\title{
THE APPLICATION OF GOOD AGRICULTURE PRACTICES (GAP) OF SHALLOT IN BANTUL REGENCY
}

\author{
Aplikasi Good Agriculture Practices (GAP) Bawang Merah Kecamatan \\ di Kabupaten Bantul
}

\author{
${ }^{1}$ Suharni, ${ }^{2}$ Lestari Rahayu Waluyati, ${ }^{2}$ Jamhari \\ ${ }^{1}$ Ditjen Hortikultura, Kementerian Pertanian,Indonesia \\ ${ }^{2}$ Master of Agribussiness Management, Faculty of Agriculture, Universitas Gadjah Mada \\ Jl. Flora, Bulaksumur, Kec.Depok, Kabupaten Sleman, \\ Daerah Istimewa Yogyakarta 55281 \\ harneesta@gmail.com
}

Diterima tanggal 16 Mei 2017 ; Disetujui tanggal 10 Juni 2017

\begin{abstract}
Bantul Regency is one of the center of shallots in Indonesia, but its productivity is low. In 2015, the productivity of shallots in Bantul Regency was 7.66 tons/ha. The application of Good Agriculture Practices (GAP) is a form of technology adoption aiming to improve the shallot productivity.The purposes of this study are to determine the level of application of shallots GAP in Bantul Regency and to find out the factors influencing the application such as land area, farmers' age, farmers' education, farming experience, availability of farm inputs, and extension service frequency. Purposive technique was used to determine the research location. Sanden and Kretek districts were discovered since these areas are the production centers of shallots in Bantul Regency. The study involved the respondents consisting of sixty shallot farmers, thirty people from Kretek District and the other thirty people from Sanden District who were determined by simple random sampling. This research used scoring technique with Likert scale to measure the application level of GAP. Multiple linear regression analysis was used to understand the factors affecting the application of GAP of shallots. Result showed that the application of GAP of shallots in Bantul Regency is low. The factors of land area, farmers' education, farming experience, and availability of farm inputs means influence the application level of GAP of shallots significantly.
\end{abstract}

Keywords: adoption of technology, application of GAP, productivity, shallot

\section{INTISARI}

Kabupaten Bantul merupakan salah satu sentra bawang merah di Indonesia, tetapi produktivitasnya masih rendah. Tahun 2015, produktivitas bawang merah di Kabupaten Bantul sebesar 7,66 ton/ha. Penerapan Good Agriculture Practices (GAP) merupakan salah satu bentuk adopsi teknologi yang bertujuan untuk meningkatkan produktivitas bawang merah. Tujuan penelitian ini adalah untuk mengetahui tingkat penerapan GAP bawang merah di Kabupaten Bantul dan mengetahui faktor-faktor yang mempengaruhi penerapannya diantaranya luas lahan, umur petani, pendidikan petani, pengalaman usahatani, ketersediaan sarana produksi, dan frekuensi penyuluhan. Pemilihan lokasi penelitian dilakukan dengan teknik purposive. Kecamatan Sanden dan Kretek dipilih karena merupakan sentra produksi bawang merah di Kabupaten Bantul. Penelitian dilakukan terhadap 60 orang petani sampel bawang merah, 30 orang dari Kecamatan Kretek dan 30 orang dari Kecamatan Sanden yang dipilih secara acak sederhana. Penelitian ini menggunakan teknik skoring dengan skala likert untuk mengukur tingkat penerapan GAP. Analisis regresi linear berganda digunakan untuk 
mengetahui faktor-faktor yang mempengaruhi penerapan GAP bawang merah. Dari hasil penelitian diketahui bahwa tingkat penerapan GAP bawang merah di Kabupaten Bantul rendah. Faktor luas lahan, pendidikan petani, pengalaman usahatani, dan ketersediaan sarana produksi berpengaruh signifikan terhadap tingkat penerapan GAP bawang merah.

Kata kunci: adopsi teknologi, bawang merah, penerapan GAP, produktivitas

\section{INTRODUCTION}

Horticulture subsector has a strategic and important position in the agricultural sector because it has a high market potential. One of the horticultural commodities that have high economic value is shallot (Wiguna et al., 2013; Theresia et al., 2016). Shallot is a spice vegetable that has high selling value and developed intensively. In economic terms, shallot business is quite profitable and has a wide market. Shallot is needed as a spice in almost all Indonesian dishes everyday. Shallot is also used in the food industry as a seasoning flavor. The consumption and demand of shallots will continue to increase in line with the increasing needs of the population due to the growing number of people, the development of the food industry and market development.

One of the central area of shallot production in Indonesia is Bantul Regency, Yogyakarta. The area of shallot harvest in Bantul Regency in 2015 reached 585 hectares with production of 4,478.9 tons and productivity of 7.66 tons/ha. This productivity decreased in the previous year which reached 10.07 tons/ha (Ministry of Agriculture, 2017). It was suppossed to obtain yields of 15-20 tons/ha with the use of good quality shallot seeds (Thamrin et al., 2003; Winarto et al., 2009; Asaad \& Warda, 2010; Azmi et al., 2011).

Several issues that resulted in low productivity of shallot in Indonesia were: (a) availability of quality seeds, (b) limited farm inputs, (c) not yet properly implemented location-specific GAP; as a result the cultivation problems were not solved (Paranata et al., 2015).

The cultivation of shallots by farmers in Indonesia generally has not fully applied the correct cultivation rules, yet in the current era of global trade, shallot farmers are required to improve the competitiveness of products to produce agricultural products that are safe to consume, good quality, and produced in an environmentally friendly manner. Today people are becoming aware that the excessive use of chemical fertilizers and pesticides used by farmers are not good for health. To improve the production, quality and competitiveness of shallot in meeting the needs of the domestic market and for export, the production process needs to be done well by applying Good Agriculture Practices (GAP).

The efforts to increase the productivity of shallots are done by introducing new technology, both local 
technology and technology produced by research institutions (Sasongko et al., 2014). One of the adoption of technology is by applying shallot GAP. The application of fruit and vegetable GAP is regulated in Minister of Agriculture Regulation number 48/ Permentan/ OT.160/10/2009 on Guidelines for Good Fruit and Vegetable Cultivation. GAP components include land issues, use of seeds and crop varieties, planting, fertilizing, crop protection, irrigation, harvesting, post harvest, agricultural machinery, environmental conservation, workers, worker welfare, landfills, surveillance, recording and traceback, and internal evaluation (Ministry of Agriculture, 2009).

The research on measuring the level of application of GAP for several commodities has been done. Sriyadi et al (2015) conducted a study on the Evaluation of Implementation of Standard Operating Procedure-Good Agriculture Practice (SOP-GAP) on Organic Rice Farming in Bantul District. This study aims to measure the level of application of SOP-GAP organic rice farming. The results showed that the level of SOP-GAP application of organic rice farming in Bantul Regency was high $(82.31 \%)$.

Research on factors influencing the application of GAP has also been done by Annor (2016). The results showed that the factors that positively affect the farmer's decision to meet GLOBAL GAP standard were land area, access of off-farm income, access to market information, and extension role, while the negative factor was age of farmer.

According to Lionberger (1968), several factors that affect a person's speed to adopt innovation are:

1. Land area, the wider land area usually the faster adopt the innovation because it has better economic capability.

2. Income level, the higher the income level usually the faster adopt the innovation.

3. Courage to take risks, individuals who have the courage to face risks are usually innovative.

4. Age, getting older (above 50 years), usually getting slower to adopt innovation.

5. Level of participation in groups or organizations outside the environment. Someone who likes to join people outside of his social system is generally more innovative.

6. Source of information utilized.

Due to the low shallot productivity in Bantul Regency, it is necessary to do research on the extent to which shallot farmers in Bantul Regency apply GAP of shallots on the agribusinesssubsystems of input provision, cultivation, post-harvest, and the factors that affect the level of application of GAP. This study aims to determine the level of application of GAP 
of shallots and to determine the factors that affect the application of GAP of shallot in Bantul Regency.

The hypothesis used in this research is that the level of application of GAP of shallots in Bantul Regency ishigh on input provision and cultivation subsystems, butstill low on postharvest subsystem. The factors that positively influence the application of GAPshallot are land area, farmer education, farming experience, availability of farm inputs, and frequency of extension service by extension officer, while the farmers' age has negative effect.

\section{METHODS}

This research was conducted on shallot farmers in Bantul Regency, Yogyakarta. The location was selected purposively, related to Kretek and Sanden as a district which has the larger shallot farming in Bantul.

The number offarmer samples used in this study was 60, 30 farmers from Kretek District and 30 farmers from Sanden District, selected by simple random sampling. The number of samples taken as many as 60 people has met the general rule statistically $\geq 30$ and able to present the state of agriculture in that location because the number of 30 samples has been normally distributed and can be used to predict the population (Hasan, 2002).

The type of data used was primary data and secondary data. Primary data were obtained from interviews and observations, while secondary data were obtained from the literature or references.

\section{Analysis of Shallot GAP Application}

The application of GAP of shallotswas divided into three subsystems, namely the provision of input, cultivation, and postharvest. The application of GAPshallot was measured by scoring technique using Likert scale. With Likert scale, the variables used were described as statements which were the indicators in measurement of the application of GAP.

The answers to the questions given in this study were given scores that are: 1 for answers of never, 2 for answers of sometimes, and 3 for answers of always.

\section{Validity and Reliability Test}

The way used to determine the validity of a measuring tool is by correlating between the scores obtained by each item (question or statement) with the total score. Validity test uses product moment correlation (pearsons correlation) as follows:

$r_{x y}=\frac{N\left(\sum X Y\right)-\left(\sum X \sum Y\right)}{\sqrt{\left(N \sum X^{2}-\left(\sum X\right)^{2}\right)\left(N \sum Y^{2}-\left(\sum Y\right)^{2}\right)}}$

$\mathrm{r}_{\mathrm{xy}}=$ coefficient of validity

$\mathrm{X}=$ item score

$\mathrm{Y}=$ total item score

$\mathrm{N}=$ respondent number 
To test the reliability of measuring equipment is calculated by using estimation of Cronbach's Alpha model that is processed with the help of SPSS program.

The GAP application scores achieved by the respondents on each subsystem are calculated on average score.Furthermore, the level of GAP application is classified into 2 categories of classes, namely low application level and high application level based on the scores obtained by respondents used intervals of the formula as follows:

$I=\frac{J}{K}$

Where:

$\mathrm{I}=$ class interval

$\mathbf{J}=$ range between maximum score (3) and minimum score (1)

$\mathrm{K}=$ The number of used class(that was 2).

The classification of GAP application level is classified based on the following scores:

1. Low application level if score $1-2$.

2. High application level if score 2.01-3

\section{Hypothesis Test}

Hypothesis test was done by testing the parameter of proportion. Test steps were determine the hypothesis $\mathrm{Ho}$ and $\mathrm{Ha}$ then calculate $\mathrm{z}$ arithmetic. The value of $\mathrm{z}$ arithmetic was obtained by the formula:

$$
Z=\frac{p-p o}{\sqrt{\frac{p o(1-p o)}{n}}}
$$

where

$\mathrm{P}=$ Percentage of GAPapplication level parameters

Po $=$ Percentage of assigned applicationlevel parameters $(0.5)$

$\mathrm{n}=$ sample number

The criterion of determination is:

Ho is accepted when $Z_{\text {arithmetic }} \leq Z_{\text {table }}$ and Ho is refused when $Z_{\text {arithmetic }}>Z_{\text {table. }}$

\section{Analysis of Factors Affecting the Level of Apllication of GAP}

To determine the factors that influence the level of application of GAP of shallot in Bantul Regency, multiple linear regression analysis was used. Application of GAP of shallot was dependent variable (Y) which was suspected to be influenced by independent variables that were land area (X1), farmers' age (X2), farmers' education level (X3), farming experience (X4), availability of farm inputs (X5), and extension service frequency (X6) which can be expressed by multiple linear regression model as follows:

$\mathrm{Y}=\mathrm{a}+\mathrm{b} 1 \mathrm{X} 1+\mathrm{b} 2 \mathrm{X} 2+\mathrm{b} 3 \mathrm{X} 3+\mathrm{b} 4 \mathrm{X} 4+$ b5X5 + b6X6

Information:

$\mathrm{Y}=$ GAPApllication (percentage of likert score)

$\mathrm{a}=$ constants

b1, b2, b3, b4, b5, b6 = regression coefficient

$\mathrm{X} 1$ = land area (hectare)

$\mathrm{X} 2$ = farmers age (year)

X3 = farmers' education level (year) 
$\mathrm{X} 4$ = shallot farming experience(year)

X5 = availability of farm inputs (score)

X6 = extension servicefrequency (times)

To meet statistical test requirements in multiple linear regression analysis, the classical assumption test using EViews program includes:

a. Normality test using Jarque-Bera (JB) Test, that is comparing JB probability value with alpha level $5 \%$.

b. Multicolinearity test, data is free from multicolinearity if all correlation coefficient between independent variables is smaller than 0.8 .

c. Heteroscedasticity test, the data is free of heteroscedasticity if the probability value of Obs*R-squaredvalue shows significant or greater result thanalpha of $1 \%$.

In addition to using the classical assumption test, this study also used hypothesis testing. The hypothesis test in this study included several tests as follows:

a. Determination coefficient test (Adjusted R²)

b. Simultaneous test(F-test)

c. Individual test (t-test)

\section{RESULTS AND DISCUSSION}

Age of respondent farmers was dominated by productive age between $15-64$ years $(81.67 \%)$. A productive age is the most appropriate age for carrying out working activities such as farming because it is physically still good, has high spirits and an obligation to support the family (Aldila et al., 2015).

Shallot farmer respondents in Bantul Regency mostly had elementary education that was equal to $38.33 \%$, while those with SMA education as much as $35.00 \%$. The level of education will affect a farmer's way of thinking and the level of technology and science absorption (Aldila et al., 2015).

Table 1. Characteristics of Respondents

\begin{tabular}{lrrr}
\hline \multicolumn{1}{c}{ Characteristics } & Groups & The number (people) & Percentage (\%) \\
\hline Ages (year) & $\leq 14$ years old & 0 & 0,00 \\
& $15-64$ ears old & 49 & 81,67 \\
& $\geq 65$ years old & 11 & 18,33 \\
\hline Education & Elementary school & 23 & 38,33 \\
& Junior high school & 15 & 25,00 \\
& Senior high school & 21 & 35,00 \\
& University & 1 & 1,67 \\
\hline Farming experience & $1-7$ & 9 & 15,00 \\
(year) & $8-14$ & 8 & 13,33 \\
& $15-21$ & 15 & 25,00 \\
& $22-28$ & 10 & 16,67 \\
& $29-35$ & 12 & 20,00 \\
& $36-42$ & 4 & 6,67 \\
& $43-49$ & 2 & 3,33 \\
\hline
\end{tabular}

Source: Analysis of Primary Data (2017) 
The level of shallot farming experience was mostly between 15-21 years $(25.00 \%)$. Level of education and farming experience will affect the way of thinking, the higher the level of education, the more responsive to new things.

\section{Level of Application of GAP of Shallots Validity Test}

Calculation of validity test with product moment correlation coefficient used SPSS program aid. $r_{\text {arithmetic }}$ of each item was compared with value in $r$ Table of product moment. In this study with the respondent number of 60 and $5 \%$ significance level, it resulted in $r_{\text {table }}$ of 0.254 . The result of validity test of GAP of shallots can be seen in Table 2.

Table 2. Validity Test Result

\begin{tabular}{clrc} 
No. & Subsystems & $\begin{array}{c}\text { The point } \\
\text { number }\end{array}$ & Valid \\
\hline 1. & Input provision & 47 & 37 \\
2. & Cultivation & 28 & 12 \\
3. & Post-harvest & 8 & 8 \\
\hline
\end{tabular}

Source: Analysis of primary data (2017)

\section{Reliability Test}

To see the reliability value,we used cronbach's alpha value that estimated using SPSS program. The value of cronbach's alpha in this study used a value of 0.6 assuming the list of questions tested would be reliable if the value of cronbach's alpha $\geq 0.6$. Reliability test results can be seen in Table 3.

Based on Table 3, it can be seen that all GAPapplication items for input provision, cultivation and postharvest subsystems have a very high reliability valuebecause cronbach's alphavalue is greater than 0.6.

\section{Hypothesis Test}

The average score of GAP application on the subsystem of input supply was 2.17 (72.18\%), on the subsystem of cultivation of $2.04(67.96 \%)$, on postharvest subsystem of $1.49(49.58 \%)$, and the average total GAP application score of 2.04(68.12\%). The results of GAP application level analysis can be seen in Table 4 .

From Table 4 it can be seen that the low level of GAP application on the input subsystem was the seed component, the low level of application of GAP in the cultivation subsystem was on the fertilization component, while the low level of application of GAP in the post-harvest subsystem were on sorting and grading, packaging, and storage.

Table 3. Reliability Test Result

\begin{tabular}{ccrcc}
\hline No. & Subsystem & Cronbach's Alpha Value & Reliability Standard number & Information \\
\hline 1. & Input provision & 0,943 & $\geq 0,6$ & Reliable \\
2. & Cultivation & 0,886 & $\geq 0,6$ & Reliable \\
3. & Post-harvest & 0,819 & $\geq 0,6$ & Reliable \\
\hline
\end{tabular}

Source: Analysis of primary data (2017) 
Table 4. The Level of Application of Shallot GAP in Bantul Regency

\begin{tabular}{|c|c|c|c|c|c|}
\hline Subsystem & Technology Components & $\begin{array}{l}\text { Maximum } \\
\text { Score }\end{array}$ & $\begin{array}{c}\text { Average } \\
\text { Score }\end{array}$ & $\begin{array}{c}\text { Percentage } \\
(\%)\end{array}$ & Criteria \\
\hline Input & Land & 3 & 2,55 & 85,00 & High \\
\hline \multirow[t]{5}{*}{ Provision } & Seed & 3 & 1,52 & 50,60 & Low \\
\hline & Fertilizer & 3 & 2,75 & 91,67 & High \\
\hline & Pesticide & 3 & 2,22 & 73,83 & High \\
\hline & $\begin{array}{l}\text { Agricultural equipment \& } \\
\text { machinery }\end{array}$ & 3 & 2,08 & 69,26 & High \\
\hline & Workers & 3 & 2,07 & 69,03 & High \\
\hline \multirow[t]{6}{*}{ Cultivation } & Land preparation & 3 & 2,52 & 83,89 & High \\
\hline & Planting & 3 & 2,53 & 84,44 & High \\
\hline & Fertilization & 3 & 1,59 & 52,89 & Low \\
\hline & Plant protection & 3 & 2,25 & 75,00 & High \\
\hline & Irrigation & 3 & 2,32 & 77,22 & High \\
\hline & Harvest & 3 & 2,34 & 78,06 & High \\
\hline Post- & Early treatment & 3 & 2,72 & 90,56 & High \\
\hline \multirow[t]{4}{*}{ harvest } & Cleaning & 3 & 2,87 & 95,56 & High \\
\hline & Sorting and Grading & 3 & 1,03 & 34,44 & Low \\
\hline & Packaging & 3 & 1,05 & 35,14 & Low \\
\hline & Storage & 3 & 1,07 & 35,56 & Low \\
\hline
\end{tabular}

Source: Analysis of primary data (2017)

Table 5. Distribution of Farmers Based on The Application Level of GAP

\begin{tabular}{|c|c|c|c|c|c|}
\hline \multirow{3}{*}{ No. } & \multirow{3}{*}{ Subsystem } & \multicolumn{4}{|c|}{ GAP Application level } \\
\hline & & \multicolumn{2}{|l|}{ Low } & \multicolumn{2}{|l|}{ High } \\
\hline & & Frequency (people) & $\%$ & Frequency (people) & $\%$ \\
\hline 1. & Input provision & 19 & 31,67 & 41 & 68,33 \\
\hline 2. & Cultivation & 29 & 48,33 & 31 & 51,67 \\
\hline & Post-harvest & 58 & 96,67 & 2 & 3,33 \\
\hline & Total GAP of shallots & 28 & 46,67 & 32 & 53,33 \\
\hline
\end{tabular}

Source: Analysis of Primary Data (2017)

To determine whether the application of shallot GAP is included in low or high criteria, then the GAP application level is classified by score into low and high application level. The distribution of farmers based on the level of application of GAP can be seen in Table 5 .

Based on Table 5, it is known that on the application of GAP as a whole, as many as 32 respondents $(53.33 \%)$ included in the category of high application level and 28 respondents $(46.67 \%)$ included in low category. Furthermore, hypothesis testing is conducted to determine the level of GAP application statistically.Hypothesis test results can be seen in Table 6 .

Based on the hypothesis test, it can be determined that:

1) The level of application of shallot GAP on the input provision subsystem was high because the farmers had used good planting media, good commercial varieties of shallot seeds, registered and permitted fertilizers and pesticides, and appropriate agricultural machinery and tools. All farmers are already using 
Table 6. Hypothesis Test Result

\begin{tabular}{|c|c|c|c|c|c|c|}
\hline No. & Subsystem & Hypothesis & $\mathrm{Z}_{\mathrm{at}}$ & $\mathrm{Z}_{\text {Tat }}$ & Conclusion & Criteria \\
\hline 1. & $\begin{array}{l}\text { Input } \\
\text { Provision }\end{array}$ & $\begin{array}{l}\text { Ho }=\mathrm{p} \leq 0.50 \text { had high } \\
\text { application of GAP } \\
\text { Ha }=p>0.50 \text { had high } \\
\text { application of GAP }\end{array}$ & 2,840 & 1,645 & $\begin{array}{l}\text { Ho refused } \\
\text { Ha accepted }\end{array}$ & High \\
\hline 2 . & Cultivation & $\begin{array}{l}\text { Ho }=p \leq 0.50 \text { had high } \\
\text { application of GAP } \\
\text { Ha }=p>0.50 \text { had high } \\
\text { application of GAP }\end{array}$ & 0,258 & 1,645 & $\begin{array}{l}\text { Ho accepted } \\
\text { Ha refused }\end{array}$ & Low \\
\hline 3. & Post-harvest & $\begin{array}{l}\text { Ho }=p \leq 0.50 \text { had low application } \\
\text { of GAP } \\
\text { Ha }=p>0.50 \text { had low application } \\
\text { of GAP }\end{array}$ & 7,230 & 1,645 & $\begin{array}{l}\text { Ho refused } \\
\text { Ha accepted }\end{array}$ & Low \\
\hline & $\begin{array}{l}\text { Total GAP of } \\
\text { Shallots }\end{array}$ & $\begin{array}{l}\text { Ho }=\mathrm{p} \leq 0.50 \text { had high } \\
\text { application of GAP } \\
\text { Ha }=\mathrm{p}>0.50 \text { had high } \\
\text { application of GAP }\end{array}$ & 0,516 & 1,645 & $\begin{array}{l}\text { Ho accepted } \\
\text { Ha refused }\end{array}$ & Low \\
\hline
\end{tabular}

Source: Analysis of Primary Data (2017)

commercial varieties of shallot seeds.

However, only $25 \%$ of respondent

farmers use labeled/ certified seed from Balai Pengawasan dan Sertifikasi Benih (BPSB). Shallot farmers also had sufficient competence for shallot cultivation because there was training from Dinas Pertanian Bantul and from Balai Pengkajian Teknologi Pertanian (BPTP) Yogyakarta.

2) The level of application of GAP of shallots on the subsystem of cultivation was lowbecause the application of GAP on fertilization is still low. Respondent farmers who used organic fertilizer before planting or at the time of processing new land reached 54\%. There are still the majority of farmers $(83.83 \%)$ did not use NPK fertilizer in recommended dose. $63.33 \%$ of farmers used NPK fertilizer under recommended dose, while $25 \%$ farmers used NPK fertilizer above recommended dose. The average use of NPK fertilizer was $500.78 \mathrm{~kg} / \mathrm{ha}$, while the recommended dose was 650 $\mathrm{kg} / \mathrm{ha}$. Utilization of fertilizers that exceed the dose was the habit of the farmers in general, the reason to the use of fertilizer more would be better results obtained.On the contrary, the reason farmers reduce doses aimed at reducing production costs.

3) The level of application of shallot GAP in postharvest subsystem was low. This shows that most farmers did not do postharvest activities of shallots. Postharvest activities carried out by farmers were only in the stages of withering and cleaning. The farmers did not sort and grading the shallots, while the shallot packaging and storage 
activities were done at the merchant level. The intensity of postharvest handling of shallot in Bantul Regency was included in the low category because farmers sold shallot directly. Farmers immediately wanted to get money quickly used for household purposes and next farming costs.

4) The overall of GAP shallot application was low. The application of the shallot GAP was still low on the seeds, fertilization, sorting and grading, packaging, and storage component.

The results of the analysis of the application of shallot GAP in Bantul Regency was in accordance with the results of research Witjaksono et al. (2012) indicating that the highest adoption rate was found in input selection innovation. The availability of production input has a significant effect on the adoption rate of technological innovation. The increasing availability of production input such as the provision of farmland, availability of seeds, fertilizers, pesticides and plant diseases, labor, the existence of financial institutions and assistance from the government will increase the adoption of technological innovation.

The Factors Affecting the Application of GAP of Shallots

\section{Classic assumption test}

Normality Test

Normality test results using the EViews program in this study showed that residual values in this study were normally distributed or met the requirements of normality. This was indicated by the JB probability value greater than the alpha of $5 \%(0.05)$ was 0.867 . The result of normality test can be seen in Figure 1 .

Multicolinearity Test

The result of multicolinearity test in this research showed that the data was free from multicollinearity, indicated by the coefficient value between variables smaller than 0.8 . The results of multicolinearity testing can be seen in Table 7 .
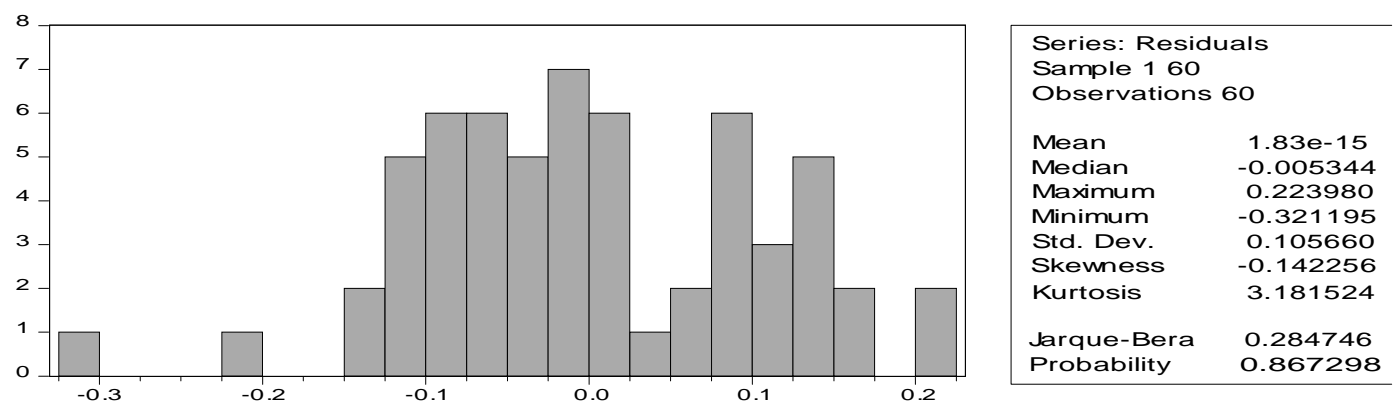

Figure 1. Normality Test Result

Source: Analysis of primary data (2017) 
Table 7. Multicollinearity Test Result

\begin{tabular}{lrrrrrr}
\hline & $\begin{array}{c}\text { Land } \\
\text { Area }\end{array}$ & $\begin{array}{c}\text { Farmers' } \\
\text { age }\end{array}$ & $\begin{array}{c}\text { Farmers' } \\
\text { Education }\end{array}$ & Experience & $\begin{array}{c}\text { Provision of } \\
\text { farm input }\end{array}$ & $\begin{array}{c}\text { Extension } \\
\text { service } \\
\text { Frequency }\end{array}$ \\
\hline Land area & 1,0000 & $-0,1664$ & 0,0954 & 0,1179 & 0,1901 & $-0,0018$ \\
Farmers' age & $-0,1664$ & 1,0000 & $-0,6698$ & 0,5243 & $-0,3078$ & $-0,1860$ \\
Farmers' Education & 0,0954 & $-0,6698$ & 1,0000 & $-0,3460$ & 0,3317 & 0,0130 \\
Experience & 0,1179 & $-0,5243$ & $-0,3460$ & 1,0000 & $-0,0210$ & $-0,0365$ \\
Provision of farm input & 0,1901 & $-0,3078$ & 0,3317 & $-0,0210$ & 1,0000 & 0,2237 \\
$\begin{array}{l}\text { Extension service } \\
\text { frequency }\end{array}$ & $-0,0018$ & $-0,1860$ & 0,0130 & $-0,0365$ & 0,2237 & 1,0000 \\
\hline Source: Anany & & & & & \\
\hline
\end{tabular}

Source: Analysis of primary data (2017)

Table 8. Heteroscedasticity Test Result

\begin{tabular}{lrr}
\hline F-statistic & 1,200 Prob, F & 0,3206 \\
Obs*R-squared & 7,1790 Prob, Chi-Square & 0,3046 \\
\hline
\end{tabular}

Source: Analysis of primary data (2017)

Heteroscedasticity Test

The results of heteroscedasticity testing in this study showed that research data was free from heteroscedasticity, indicated by the value of Obs*R-squared 0.305 which was significant or greater than the alpha of $1 \%$ as shown in Table 8 .

\section{Hypothesis Test}

Determination Test (Adjusted $\mathrm{R}^{2}$ )

The results of data processing factors influencing the application of GAP of shallots in Bantul Regency showed that correlation coefficient value (adjusted $\mathrm{R}^{2}$ ) was 0.553 . The value of adjusted $R^{2}$ shown in this study was quite good because the correlation between the dependent variable and the independent variable was called strong if the value of adjusted $R^{2}$ was above 0.5 . The result of adjusted $\mathrm{R}^{2}$ test in this research stated that the model used was able to explain the application level of GAP of shallots in Bantul Regency (55.3\%), while the rest $(44.7 \%)$ was caused by variable outside model. The results of adjusted $\mathrm{R}^{2}$ test can be seen in Table 9 .

Based on the output of regression analysis in Table 9, it can be mathematically writtenregression model between the variable levelsof GAPapplication with variables that influenced it in the following equation:

$\mathrm{Y}=1.652+0.058 \mathrm{x}_{1}+0.122 \mathrm{x}_{3}+0.045$

$\mathrm{x}_{4}+0.944 \mathrm{x}_{5}$

Simultaneous Test

After the simultaneous test of the factors affecting the level of GAPapplication, it can be said that together the factors of land area, farmers' age, farmers' education level, farming experience, availability of farm inputs, and extension service frequency 
Table 9. Regression Analysis Test Result

\begin{tabular}{lccc}
\hline \multicolumn{1}{c}{ Variable } & Expected Sign & Coefficient & Prob. \\
\hline $\mathrm{C}$ & $+/-$ & $1,652^{* *}$ & 0,025 \\
Land area $(\mathrm{x})$ & + & $0,058^{* * *}$ & 0,007 \\
Farmers'age $\left(\mathrm{x}_{2}\right)$ & - & $-0,026^{\mathrm{ns}}$ & 0,770 \\
Farmers' ed cation $\left(\mathrm{x}_{3}\right)$ & + & $0,122^{*}$ & 0,066 \\
Farming exp srience $\left(\mathrm{x}_{4}\right)$ & + & $0,045^{* *}$ & 0,027 \\
Provision of farm input $\left(\mathrm{x}_{5}\right)$ & + & $0,944^{* * *}$ & 0,000 \\
Extension service frequency $\left(\mathrm{x}_{6}\right)$ & + & $0,052^{\mathrm{ns}}$ & 0,114 \\
\hline R-squared & & 0,599 & \\
Adjusted R-squared & & 0,553 & \\
F-statistic & & 13,174 & \\
Prob(F-statistic) & & 0,000 & \\
$* \quad$ Significant $\alpha=10 \%$ & & & \\
$* *$ Significant $\alpha=5 \%$ & & & \\
$* * *$ Significant $\alpha=1 \%$ & & &
\end{tabular}

significantly affected the application level of GAP of shallots in Bantul Regency at a significant level of 5\%. This is shown by Table9 where the value of $\mathrm{P}$ - value $<\alpha=$ $5 \%(0.000<0.05)$.

Individual Test

The analysis of independent variables affecting the application of GAP of shallots in Bantul Regency showed that variables that had significant influence were land area (X1), farmers' education (X3), farming experience (X4), and availability of farm inputs (X5). Meanwhile,farmers' age (X2) and extension service frequency (X6) did not significantly influence the level of application of GAP.

\section{Land Area}

Land area had significant effect on the level of $1 \%$ significant to the level of application of shallotGAP in Bantul Regency. This can be seen in Table 9 where p-value $<\alpha=1 \%(0.007<0.01)$ with regression coefficient of 0.058 . Other variables were assumpted as ceteris paribusso the 1 unit increase of land area would increase the application of GAP by 0.058 .

The results of this study was in accordance with research of Nurkholipah et al. (2015) stating that the more land the farmers occupy, the higher the adoption rate of the technology. With large land, farmers have a very high willingness to apply cultivation technology as directed in order to yield greater productivity. Farmers will increasingly respond to technology capable of managing their farms to increase revenue. Besides that, the wider land area usually the faster adopt the innovation because it has better economic capability (Lionberger, 1968).

\section{Age of Farmer}

The significance value of farmer age variable was 0.770 which means greater 
than $\alpha=10 \%$ or 0.10 so it can be concluded that the age of farmers had no significant effect on the application level of shallot GAP. According to Lionberger (1968). getting older age (above 50 years), usually getting slower to adopt innovation. Younger farmers usually have a passion for wanting to know what they do not know yet, so trying to accelerate adoption of innovation. But, in this study indicated that the younger farmers, not necessarily the higher level of application of GAP because in general young farmers still had a little experience farming. The results of this study were in accordance with the research of Lalla et al. (2012) stating that the age factor did not provide a significant relationship to the rate of technology adoption.

\section{Farmers Education Level}

Farmers' education significantly influenced at a significant level of $10 \%$ on the level of application of shallotGAP in Bantul Regency. This can be seen in Table 9 where the $\mathrm{p}$-value $<\alpha=10 \%(0.066<$ 0.10 ) with regression coefficient of 0.122 . Assuming other variables ceteris paribus, the increase in farmers' education by 1 unit would increase the application of GAP of 0.122 .

The results of this study were in accordance with the results of research conducted by Pongvinyoo et al. (2014) on Factors Influencing the Implementation of Good Agricultural Practices (GAP) in
Coffee Farmers in Chumphon Province, Thailand. The results showed that the education level of farmers had a positive effect.

\section{Farming Experience}

Farming experience had a significant effect on a significant level of $5 \%$ on the level of application of shallotGAP in Bantul Regency. This can be seen in Table9 where p-value $<\alpha=5 \%(0.027<0.05)$ with regression coefficient of 0.045 . Assuming other variables ceteris paribus, the increase of farming experience by 1 unit would increase the application of GAP of 0.045 .

Rukka et al. (2006) states that the experience of farmers in farming has an effect on how to respond to an innovation. The longer the experience of farming, the level of response to a technology will be higher.

5. The availability of farm inputs

The availability of farm inputs had significant influence at a significant level of $1 \%$ on the level of application of shallotGAP in Bantul Regency. This can be seen in Table9 where p-value $<\alpha=1 \%$ $(0.00<0.01)$ with regression coefficient of 0.944. Assuming other variables of ceteris paribus, the increase of farm inputs availability by 1 unit would increase the application of GAP of 0.944 .

The availability of farm inputs significantly influenced the adoption 
rate of technological innovation. The higher the availability of farm inputs such as the provision of farmland, the availability of seeds, fertilizers, pesticides and plant diseases, labor, the existence of financial institutions and assistance from the government, the higher the adoption of technological innovation. It was in line with Basuki's opinion (2014) that input issues (land, quality seeds, fertilizers, pesticides, and labor) affected farmers' ability to produce shallots optimally.

6. The frequency of extension service

The frequency of extension service had no significant effect on GAPapplication level. This indicated that extension service by extension officer was not optimal due to several things such as the extension service methods that had not been well targeted, unaprroppiate approaches to farmers, and the extension service materials that were less appropriate to the needs of farmers.

The results of this study were in accordance with research conducted by Nurkholipah et al (2015) stating that the role of extension officer did not affect the level of adoption of sorghum technology. Most of the farmers (56.67\%) rated that extension officer had a poor role to the innovation of sorghum cultivation, although counselors rarely provided technical information about sorghum cultivation, but the farmers continued to cultivate sorghum as recommended.

\section{CONCLUSION AND SUGGESTION}

\section{Conclusion}

a. The application level of GAP of shallots in Bantul Regency was low.

b. Land area, farmers' education, farming experience, and availability of farm inputs affected on the application of GAP of shallots in Bantul Regency.

\section{Suggestion}

a. It is necessary to improve the application of GAP of shallots in Bantul Regency, especially in the cultivation subsystem that is by doing fertilization according to recommended doses and in the postharvest subsystem, by sorting, grading, packing and storage of shallot well.

b. Improving the quality of agricultural extension officer to be more competent in providing counseling to farmers.

\section{REFERENCES}

Aldila, H. F., Fariyanti, A., Tinaprilla, N. 2015. Analisis profitabilitas usahatani bawang merah berdasarkan musim di tiga kabupaten sentra produksi di Indonesia. Jurnal SEPA 11(2): 249-260.

Annor, B.P. 2016. Compliance with GLOBALGAP standards among smallholder pineapple farmers in Akuapem-South, Ghana. Journal of Agribusiness in Developing and Emerging Economies 6: 21-38.

Asaad, M.\& Warda. 2010. Kajian penggunaan pupuk organik pada tanaman bawang merah asal biji di Kabupaten Sidrap, Sulawesi 
Selatan. Jurnal Pengkajian dan Pengembangan Teknologi Pertanian13(1):20-28.

Azmi, C., Hidayat, I.M., \& Wiguna, G. 2011. Pengaruh varietas dan ukuran umbi terhadap produktivitas bawang merah. Jurnal Hortikultura 21(3): 206-213.

Basuki, R.S. 2014. Identifikasi permasalahan dan analisis usahatani bawang merahdi dataran tinggi pada musim hujan di Kabupaten Majalengka. Jurnal Hortikultura 24(3): 266-275.

Hasan, M. I. 2002. Pokok-pokok Materi Metodologi Penelitian dan Aplikasinya. Ghalia Indonesia. Bogor.

Lalla, H., Ali, M. S. S, \& Saadah.2012. Adopsi petani padi sawah terhadap sistem tanam jajar legowo 2:1 di Kecamatan Polongbangkeng Utara, Kabupaten Takalar. Jurnal Sains \& Teknologi 12(3): 255-264.

Lionberger, H.F. 1968. Adoption of new ideas and practices. $5^{\text {th }}$ Print. Iowa: The Iowa State University Press.

Ministry of Agriculture. 2009. Peraturan Menteri Pertanian No. 48/Permentan/ OT.140/10/2009 tentang pedoman budidaya buah dan sayur yang baik (Good Agriculture Practices for fruit and Vegetables). Jakarta.

Ministry of Agriculture. 2017. Produksi, luas panen, dan produktivitas sayuran di Indonesia. http://www. pertanian.go.id/Indikator/tabel-2prod-lspn-prodvitas-horti.pdf. [7 May 2017].

Nurkholipah, Subejo, \& Harsoyo. 2015. Adopsi teknologi budidaya sorgum di Desa Poncosari Kecamatan Srandakan Kabupaten Bantul. Jurnal Agro Ekonomi 26(1): 91-102.
Paranata, A. \& Umam, A. T. 2015. Pengaruh harga bawang merah terhadap produksi bawang merah di Jawa Tengah. JEJAK Journal of Economics and Policy 8(1): 36-44.

Pongvinyoo, P., Yamao,M., \& Hosono, K. 2014. Factors affecting the implementation of Good Agricultural Practices (GAP) among coffee farmers in Chumphon Province, Thailand. American Journal of Rural Development2(2): 34-39.

Rukka, H., Buhaerah,\& Sunaryo. 2006. Hubungan karakteristik petani dengan respon petani terhadap penggunaan pupuk organik pada padi sawah (Oryza sativa L.). Jurnal Agrisistem 2(1): 12-18.

Sasongko, W.A., Witjaksono, R., \& Harsoyo. 2014. Pengaruh perilaku komunikasi terhadap sikap dan adopsi teknologi budidaya bawang merah di lahan pasir pantai Kecamatan Sanden Kabupaten Bantul. Jurnal Agro Ekonomi24(1): 35-43.

Sriyadi, Istiyanti, E., \& Fivintari, F. R. 2015. Evaluasi penerapan Standard Operating Procedure-Good Agriculture Practice (SOP-GAP) pada usahatani padi organik di Kabupaten Bantul. J. Agraris 1(2): 78-84.

Thamrin, Ramlan, M., Armiati, Ruchjatiningsih, \&Wahdania. 2003. Pengkajian sistim usahatani bawang merah di Sulawesi Selatan. Jurnal Pengkajiandan Pengembangan Teknologi Pertanian 6(20):141-153.

Theresia, V., Fariyanti, A., \& Tinaprilla, N. 2016. Analisis persepsi petani terhadap penggunaan benih bawang merah lokal dan impor di Kabupaten Cirebon, Jawa Barat. Jurnal Penyuluhan 12(1): 74-88. 
Wiguna, G., Hidayat, I.M., \& Azmi, C. 2013. Perbaikan teknologi produksi benih bawang merah melalui pengaturan pemupukan, densitas, dan varietas. J. Hort. 23(2): 137-142.

Winarto, L., Prama, M. Y., \& Haloho, L. 2009. Kajian paket teknologi bawang merah di Haranggaol Sumatera Utara. Jurnal Pengkajian dan Pengembangan Teknologi Pertanian 12(1):1-10.

Witjaksono, R., Mudiyono, \& Hariadi, S. S. 2012. Aksesibilitas petani dalam agribisnis bawang merah di lahan pasir pantai Kecamatan Sanden Kabupaten Bantul. Jurnal Agriekonomika1(2): 89-102. 